\title{
Interlaboratory Trial for Measurement of Vitamin D and 25- Hydroxyvitamin D [25(OH)D] in Foods and a Dietary Supplement Using Liquid Chromatography-Mass Spectrometry
}

Janet Maxwell Roseland, ${ }^{*}{ }^{\dagger}$ Kristine Y. Patterson, ${ }^{\dagger}$ Karen W. Andrews, ${ }^{\dagger}$ Katherine M. Phillips, ${ }^{\Sigma}$ Melissa M. Phillips, ${ }^{\S}$ Pamela R. Pehrsson, ${ }^{\dagger}$ Guy L. Dufresne, ${ }^{\perp}$ Jette Jakobsen, ${ }^{\otimes}$ Pavel A. Gusev, ${ }^{\dagger}$ Sushma Savarala, ${ }^{\dagger}$ Quynhanh V. Nguyen, ${ }^{\dagger}$ Andrew J. Makowski, ${ }^{\Delta}$ Chad R. Scheuerell, ${ }^{\#}$ Guillaume P. Larouche, ${ }^{\perp}$ Stephen A. Wise, ${ }^{\S}$ James M. Harnly, ${ }^{\ddagger}$ Juhi R. Williams, ${ }^{\dagger}$ Joseph M. Betz, ${ }^{\Pi}$ and Christine L. Taylor ${ }^{\Pi}$

\footnotetext{
${ }^{\dagger}$ Nutrient Data Laboratory, Agricultural Research Service, U.S. Department of Agriculture, 10300 Baltimore Avenue, Building 005, BARC-West, Beltsville, Maryland 20705, United States

${ }^{\Sigma}$ Biochemistry Department (0308), Virginia Tech, 304 Engel Hall, Blacksburg, Virginia 24061, United States

${ }^{\S}$ Chemical Sciences Division, National Institute of Standards and Technology, MS 8392, 100 Bureau Drive, Gaithersburg, Maryland 20899-8392, United States

${ }^{\perp}$ Food and Nutrition Laboratory, Health Canada, 1001 St-Laurent Ouest, Longueuil, Québec, Canada J4K IC7

${ }^{\otimes}$ Division of Food Chemistry, National Food Institute, Technical University of Denmark, Søborg, Denmark

${ }^{\Delta}$ Heartland Assays, LLC, Suite 4400, 2711 South Loop Drive, Ames, Iowa 50010, United States

${ }^{\#}$ Covance Laboratories, 3301 Kinsman Boulevard, Madison, Wisconsin 53704, United States

${ }^{\Pi}$ Office of Dietary Supplements, National Institutes of Health, 3B01, MSC 7517, 6100 Executive Boulevard, Bethesda, Maryland 20892, United States

${ }^{\ddagger}$ Food Composition and Method Development Laboratory, Agricultural Research Service, U.S. Department of Agriculture, Building 161, BARC-East, 10300 Baltimore Avenue, Beltsville, Maryland 20705, United States
}

Supporting Information

ABSTRACT: Assessment of total vitamin D intake from foods and dietary supplements (DSs) may be incomplete if 25hydroxyvitamin D $[25(\mathrm{OH}) \mathrm{D}]$ intake is not included. However, $25(\mathrm{OH}) \mathrm{D}$ data for such intake assessments are lacking, no food or DS reference materials (RMs) are available, and comparison of laboratory performance has been needed. The primary goal of this study was to evaluate whether vitamin $\mathrm{D}_{3}$ and $25(\mathrm{OH}) \mathrm{D}_{3}$ concentrations in food and $\mathrm{DS}$ materials could be measured with acceptable reproducibility. Five experienced laboratories from the United States and other countries participated, all using liquid chromatography tandem-mass spectrometry but no common analytical protocol; however, various methods were used for determining vitamin $\mathrm{D}_{3}$ in the DS. Five animal-based materials (including three commercially available RMs) and one DS were analyzed. Reproducibility results for the materials were acceptable. Thus, it is possible to obtain consistent results among experienced laboratories for vitamin $\mathrm{D}_{3}$ and $25(\mathrm{OH}) \mathrm{D}_{3}$ in foods and a $\mathrm{DS}$.

KEYWORDS: reference material, food, dietary supplement, vitamin $D_{3}$ (cholecalciferol),

25-hydroxyvitamin $\mathrm{D}_{3}$ (25-hydroxycholcalciferol)

\section{INTRODUCTION}

Vitamin D deficiency is a worldwide concern because of its major health consequences, including rickets and the postulated increased risk of other diseases. ${ }^{1-3}$ Numerous epidemiological evaluations of vitamin $\mathrm{D}$ intake and vitamin $\mathrm{D}$ status have been reported, as have studies on the relationship of these factors with occurrence of various diseases. ${ }^{4-8}$ Humans and animals obtain vitamin $\mathrm{D}_{3}$ (cholecalciferol) from dietary sources and from synthesis when 7-dehydrocholesterol in the skin is exposed to UV light. ${ }^{9}$ Vitamin $D_{3}$ is the primary form in the diet, although vitamin $\mathrm{D}_{2}$ (ergocalciferol) can be present in some foods and supplements. ${ }^{5-7,10-13}$ These "parent" compounds of vitamin $\mathrm{D}$ are metabolized by humans and animals to
$25(\mathrm{OH}) \mathrm{D}$ and other metabolites before they are used by the body. Therefore, animal tissue-and, in turn, animal-derived human foods-contain 25-hydroxyvitamin D [25( OH)D] as well as the parent vitamin $\mathrm{D}$, and the $25(\mathrm{OH}) \mathrm{D}$ can contribute to the overall vitamin $\mathrm{D}$ value of the food. In fact, evidence suggests that the content of $25(\mathrm{OH}) \mathrm{D}$ may be $2-5$ times more potent than the content of parent vitamin D. ${ }^{10-12}$ Therefore,

Received: October 26, 2015

Revised: April 4, 2016

Accepted: April 5, 2016

Published: April 5, 2016 
accurate estimates of dietary vitamin $\mathrm{D}$ intake require the inclusion of the $25(\mathrm{OH}) \mathrm{D}$ content of foods. ${ }^{13}$

Current estimates of vitamin $\mathrm{D}$ intake suggest that many people in the United States consume considerably less than the established dietary requirement. ${ }^{14}$ The serum 25(OH)D concentrations of the U.S. population, an indicator of vitamin $\mathrm{D}$ status, are higher than expected on the basis of estimated vitamin D intakes alone. ${ }^{15,16}$ Although sun exposure is often cited as a major factor in this discrepancy, another possibility is the failure to account for intakes of $25(\mathrm{OH}) \mathrm{D}$ in foods. This potentially important omission could result in a significant underestimation of vitamin $\mathrm{D}$ intake because the reliability of calculated vitamin $\mathrm{D}$ intake rests heavily on the trueness and availability of food composition data, ${ }^{13}$ which do not typically include $25(\mathrm{OH}) \mathrm{D}$ assessments. For example, information on vitamin $\mathrm{D}$ in the major source of food composition data in the United States, the U.S. Department of Agriculture's (USDA's) National Nutrient Database for Standard Reference, ${ }^{17}$ is currently being updated, ${ }^{18}$ but it does not provide $25(\mathrm{OH}) \mathrm{D}$ values. Some limited data on the $25(\mathrm{OH}) \mathrm{D}$ content of foods are available in other databases outside the United States, ${ }^{19,20}$ but the lack of data in the United States on $25(\mathrm{OH}) \mathrm{D}_{3}$ in foods and the extent to which dietary $25(\mathrm{OH}) \mathrm{D}_{3}$ contributes to vitamin $\mathrm{D}$ status merit further exploration.

In addition to limited $25(\mathrm{OH}) \mathrm{D}$ measurements in food composition data, the lack of reliable food composition data on vitamin $\mathrm{D}$ is also due to uncertainty about the accuracy (trueness and precision) of the methods used to generate such data. Furthermore, obtaining reliable estimates of average concentrations in foods and sources of variability in the food supply, as well as in dietary supplements (DSs), requires representative sampling, validated analytical methods, expert analysts, and accredited, documented quality-control measures.

In the 1990s and early 2000s, the methodology for quantification of vitamin $\mathrm{D}_{3}$ and $25(\mathrm{OH}) \mathrm{D}_{3}$ used highperformance liquid chromatography (HPLC) with UV detection, which necessitated time-consuming cleanup steps to obtain accurate results. ${ }^{21,22}$ Recent progress has been made in the development of methodology for the quantitation of vitamin $\mathrm{D}$ in foods using liquid chromatography-tandem mass spectrometry (LC-MS/MS) for measurements of vitamin $\mathrm{D}_{3}$ and $25(\mathrm{OH}) \mathrm{D}_{3}{ }^{23-27}$

When published values from different studies are compared, variability due to real differences in food composition versus those due to differences in analytical methodology and skill in assay performance cannot be discerned in the absence of common control or reference samples. In a 2008 study $^{28}$ that quantified vitamin $\mathrm{D}_{3}$ in the same five food matrices at six experienced laboratories, each using their standard in-house methodology, the results showed various degrees of difference among the foods and laboratories. Whether this variability was due to differences in the methods used and/or individual skills in laboratory procedures is an open question. Differences in matrix and analyte levels can affect assay performance even when the same basic methodology is used. Therefore, control and reference materials representing different food matrices are needed to ensure the trueness and precision of quantitative results across a wide spectrum of foods.

The first specific aim of this study was to determine whether vitamin $\mathrm{D}_{3}$ and $25(\mathrm{OH}) \mathrm{D}_{3}$ concentrations in a range of animalbased food matrix materials and a DS could be measured with acceptable reproducibility by laboratories that are experienced in vitamin $\mathrm{D}$ analysis, without a common analytical protocol.
The secondary aim was to assess the potential for the use of the materials as control or reference materials in future research.

\section{MATERIALS AND METHODS}

Overview. Through an interagency agreement between the Nutrient Data Laboratory (NDL; Beltsville, MD, USA) of the USDA Agricultural Research Service and the Office of Dietary Supplements of the National Institutes of Health (Bethesda, MD, USA), NDL designed and conducted a pilot study that measured vitamin D and $25(\mathrm{OH}) \mathrm{D}$ levels in foods and a DS. A "roundtable" group of five experts identified and critically evaluated scientific issues related to sample selection, preparation, distribution, and tracking as well as laboratory participation and evaluation of results. The roundtable members were representatives from Health Canada (Longueuil, Quebec, Canada), U.S. Food and Drug Administration (College Park, MD, USA), National Institute of Standards and Technology (NIST; Gaithersburg, MD, USA), and USDA's Food Composition and Method Development Laboratory (Beltsville, MD, USA). In addition, scientists from the Office of Dietary Supplements participated in the roundtable discussions. Five animal-based foods and one DS were selected by NDL in consultation with the roundtable group. Samples were prepared at a central location and distributed to each laboratory on two occasions for analysis of vitamin $\mathrm{D}$ and 25( $\mathrm{OH}) \mathrm{D}$ contents.

Identification of Participating Laboratories. NDL identified analytical laboratories with expertise in measuring vitamin $\mathrm{D}$ and $25(\mathrm{OH}) \mathrm{D}$ in various matrices. These laboratories had either published their vitamin D methodology or had previously provided NDL with vitamin $\mathrm{D}$ data that met data quality evaluation standards. ${ }^{29}$ The participating laboratories were Covance Laboratories (Madison, WI, USA), Health Canada (Longueuil, Quebec, Canada), Heartland Laboratories (Ames, IA, USA), NIST (Gaithersburg, MD, USA), and the Technical University of Denmark (Søborg, Denmark). All of the laboratories were using LC-MS/MS for separation, detection, and quantitation but varied analytical protocols to analyze vitamin $\mathrm{D}$ and $25(\mathrm{OH}) \mathrm{D}$ contents. Two of the laboratories also had experience analyzing DSs for vitamin D content. The five laboratories are identified in this report using randomly assigned letters A-E.

Selection of Food Samples. Standard animal-based food reference materials from NIST that could contain $25(\mathrm{OH}) \mathrm{D}_{3}$ were initially considered for the study, including NIST Standard Reference Material (SRM) 1577c Bovine Liver, NIST SRM 1546a Meat Homogenate, and NIST SRM 1845a Whole Egg Powder.

Foods included in the initial screening were cooked chicken liver, cooked beef liver, rotisserie chicken with skin, a cooked pork and egg yolk composite, and cooked ground beef. The materials chosen for screening represented a variety of food matrices with potential for measurable levels of $25(\mathrm{OH}) \mathrm{D}$.

NDL collaborated with scientific partners at Virginia Tech (Blacksburg, VA, USA) to screen these materials and samples of other foods for vitamin $\mathrm{D}_{3}$ and $25(\mathrm{OH}) \mathrm{D}_{3}$ contents. A homogeneous composite of locally procured (Blacksburg, VA, USA) retail samples of chicken liver, beef liver, and rotisserie chicken was prepared for each of these three foods using validated protocols. ${ }^{28,30}$ The ground beef and the pork and egg yolk samples had been previously prepared using the same protocols for use as control materials in the USDA National Food and Nutrient Analysis Program. ${ }^{30}$ Subsamples of all composites were maintained in glass jars, sealed under nitrogen at $-60{ }^{\circ} \mathrm{C}$ and protected from light. The frozen samples were shipped on dry ice via express overnight delivery to Covance Laboratories, where they were analyzed for vitamin $\mathrm{D}_{3}$ and $25(\mathrm{OH}) \mathrm{D}_{3}$ contents.

The screening results were evaluated by the roundtable experts who selected the following materials to represent a range of expected vitamin $\mathrm{D}_{3}$ and $25(\mathrm{OH}) \mathrm{D}_{3}$ concentrations and diverse matrices in this study: NIST SRM 1577c Bovine Liver; NIST SRM 1546a Meat Homogenate; NIST SRM 1845a Whole Egg Powder; cooked chicken liver; and cooked ground beef. The roundtable experts selected these materials because they were sufficiently diverse to represent variability in method performance based on specific matrix characteristics that 
Table 1a. Methodology Used by Participating Laboratories To Analyze Vitamin D Content in Foods and 25(OH)D Content in Foods and a Dietary Supplement ${ }^{b}$

\begin{tabular}{|c|c|c|c|c|c|}
\hline & Laboratory A & Laboratory B & Laboratory C & Laboratory D & Laboratory $\mathrm{E}$ \\
\hline $\begin{array}{l}\text { Method } \\
\text { reference }\end{array}$ & $\begin{array}{l}\text { Huang, M.; LaLuzerne, } \\
\text { P.; Winters, D.; Sullivan, } \\
\text { D., Measurement of } \\
\text { vitamin D in foods and } \\
\text { nutritional supplements } \\
\text { by liquid } \\
\text { chromatography/tandem } \\
\text { mass spectrometry. J } \\
\text { AOAC Int 2009, 92, } \\
1327-1335 .\end{array}$ & Not available & Not available & $\begin{array}{l}\text { Burild, A.; Frandsen, H. } \\
\text { L.; Poulsen, M.; } \\
\text { Jakobsen, J., } \\
\text { Quantification of } \\
\text { physiological levels of } \\
\text { vitamin D(3) and 25- } \\
\text { hydroxyvitamin D(3) in } \\
\text { porcine fat and liver in } \\
\text { subgram sample sizes. J. } \\
\text { Sep. Sci. 2014, 37, 2659- } \\
2663 \text {. }\end{array}$ & Not available \\
\hline Sample size & $\begin{array}{l}3 \mathrm{~g} \text { to } 10 \mathrm{~g} \text { depending on } \\
\text { moisture content }\end{array}$ & $\begin{array}{l}0.8 \mathrm{~g} \text { to } 3 \mathrm{~g} \text { depending on } \\
\text { moisture content }\end{array}$ & $0.6 \mathrm{~g}$ to $2 \mathrm{~g}$ & $1 \mathrm{~g}$ & $2 \mathrm{~g}$ to $3 \mathrm{~g}$ \\
\hline Internal standard & $\begin{array}{l}\left({ }^{2} \mathrm{H}_{3}\right) \text { vitamin } \mathrm{D}_{3} \text { and } \\
\left({ }^{2} \mathrm{H}_{3}\right) 25(\mathrm{OH}) \mathrm{D}_{3} \\
\text { (IsoSciences, King of } \\
\text { Prussia, PA) }\end{array}$ & $\begin{array}{l}\left({ }^{2} \mathrm{H}_{6}\right) \text { vitamin } \mathrm{D}_{3} \text { and } \\
\left({ }^{2} \mathrm{H}_{6}\right) 25(\mathrm{OH}) \mathrm{D}_{3} \\
\text { (Chemaphor, Ottawa, } \\
\text { Canada) }\end{array}$ & $\begin{array}{l}\left({ }^{3} \mathrm{H}\right) \text { vitamin } \mathrm{D}_{3} \text { (in-house) } \\
\text { and }\left({ }^{2} \mathrm{H}_{3}\right) 25(\mathrm{OH}) \mathrm{D}_{3} \\
\text { (Sigma-Aldrich) }\end{array}$ & $\begin{array}{l}\left({ }^{2} \mathrm{H}_{6}\right) \text { vitamin } \mathrm{D}_{3} \text { and } \\
\left({ }^{2} \mathrm{H}_{6}\right) 25(\mathrm{OH}) \mathrm{D}_{3} \\
\text { (Chemaphor, Ottawa, } \\
\text { Canada) }\end{array}$ & $\begin{array}{l}\left({ }^{13} C_{5}\right) \text { vitamin } D_{3} \text { and } \\
\left({ }^{13} C_{5}\right) 25(O H) D_{3} \\
\text { (IsoSciences, King of } \\
\text { Prussia, PA) }\end{array}$ \\
\hline Initial treatment & $\begin{array}{l}\text { reagent-grade alcohol } \\
\text { with } 2 \% \text { pyrogallic acid, } \\
50 \% \mathrm{KOH} \text { added }\end{array}$ & $\begin{array}{l}10 \mathrm{~mL} \text { pyrogallol } 1 \% \text { in } \\
\text { EtOH and } 8 \mathrm{~mL} \mathrm{KOH} \\
60 \%\end{array}$ & methanoic $\mathrm{KOH}$ & $\begin{array}{l}\text { sodium ascorbate, } \mathrm{KOH} \text {, } \\
\text { and ethanol }\end{array}$ & lipase and ethanol \\
\hline Lipid treatment & $\begin{array}{l}\text { saponification under } \mathrm{N}_{2} \\
\text { overnight }\end{array}$ & $\begin{array}{l}\text { saponification under } \mathrm{N}_{2} \text { at } \\
\text { room temperature } \\
\text { overnight }\end{array}$ & $\begin{array}{l}\text { saponification for } 2 \text { hours } \\
\text { at } 60^{\circ} \mathrm{C}\end{array}$ & $\begin{array}{l}\text { saponification under } \mathrm{N}_{2} \text { at } \\
\text { room temperature for } 16- \\
18 \text { hours }\end{array}$ & $\begin{array}{l}\text { enzymatic digestion for } 2 \\
\text { hours at } 37^{\circ} \mathrm{C}\end{array}$ \\
\hline Extraction step & $\begin{array}{l}\text { solution of } 30 \mathrm{~mL} 20 \% \\
\text { ether and } 80 \% \text { hexane }\end{array}$ & $\begin{array}{l}3 x \text { petroleum } \\
\text { ether/diethyl ether }(80 / 20)\end{array}$ & $\begin{array}{l}3 x \text { hexane/ethyl acetate } \\
(85 / 15)\end{array}$ & $\begin{array}{l}\text { ethyl acetate/n-heptane } \\
(20 / 80)\end{array}$ & $\begin{array}{l}2 \mathrm{x} \text { hexane extracted, } \\
\text { pooled, with addition of } \\
\sim 1 \mathrm{~g} \mathrm{MgSO} 4 \text { to remove } \\
\text { extra water; centrifuged; } \\
\text { and dried }\end{array}$ \\
\hline Clean-up step & $\begin{array}{l}\text { dried and redissolved in } 1 \\
\mathrm{~mL} 70 \% \text { acetonitrile- } \mathrm{H}_{2} \mathrm{O} \\
\text { [not done for } 25(\mathrm{OH}) \mathrm{D}]\end{array}$ & $\begin{array}{l}\text { organic phase washed } \\
\text { with water, taken to } \\
\text { dryness, and dissolved in } \\
800 \text { 1-chlorobutane }\end{array}$ & $\begin{array}{l}\text { dried and redissolved in } 1 \\
\mathrm{~mL} \text { hexane/methylene } \\
\text { chloride }\end{array}$ & $\begin{array}{l}\text { dried and redissolved in } \\
\text { 2-propanol in n-heptane }\end{array}$ & \\
\hline $\begin{array}{l}\text { Additional clean- } \\
\text { up }\end{array}$ & & $\begin{array}{l}\text { purified using HPLC } \\
\text { normal phase (silica } \\
\text { column) and fractions } \\
\text { collection }\end{array}$ & $\begin{array}{l}\text { loaded into an SPE } \\
\text { cartridge, eluted with } \\
\text { methylene } \\
\text { chloride/isopropanol, two } \\
\text { cleanings through HPLC } \\
\text { columns, final solution } \\
\text { methylene chloride and } \\
\text { isopropanol }\end{array}$ & $\begin{array}{l}\text { loaded onto a silica SPE } \\
\text { cartridge, rinsed with } 0.5 \\
\% \text { 2-propanol in n- } \\
\text { heptane, eluted with } 6 \% \\
\text { and } 10 \% \text { 2-propanol in } \\
\text { n-heptane }\end{array}$ & \\
\hline Derivatization & $\begin{array}{l}\text { evaporated to dryness } \\
\text { and } 2 \mathrm{mg} / \mathrm{mL} \text { PTAD in } \\
100 \% \mathrm{ACN} \text { added. }\end{array}$ & $\begin{array}{l}\text { fractions evaporated to } \\
\text { dryness, PTAD reagent in } \\
\text { ethyl acetate added, } \\
\text { evaporated to dryness, } \\
\text { reconstituted in } 0.2 \mathrm{~mL} \text { of } \\
\text { methanol }\end{array}$ & not derivatized & $\begin{array}{l}\text { dried under } \mathrm{N}_{2} \text { and } \\
\text { derivatized with PTAD in } \\
\text { anhydrous acetonitrile, } \\
\text { solvent evaporated, } \\
\text { sample reconstituted in } \\
60 \% \text { methanol }\end{array}$ & $\begin{array}{l}\text { derivatized with PTAD in } \\
\text { acetonitrile, dried, } \\
\text { reconstituted in } 500 \mathrm{uL} \\
70: 30 \text { methanol:water. }\end{array}$ \\
\hline HPLC column & $\begin{array}{l}\text { Thermo, UHPLC column, } \\
\text { Hypersil GOLD aQ } \\
(1.9 \mu \mathrm{m}) 100 \mathrm{~mm} \times 2.1 \\
\mathrm{~mm}\end{array}$ & $\begin{array}{l}\text { Phenomenex LUNA-C18 } \\
\text { ( } 3.0 \mathrm{um}) 150 \mathrm{~mm} \times 2.1 \\
\mathrm{~mm}\end{array}$ & $\begin{array}{l}\text { Supelco-Sil LC-18 ODS } \\
\text { column }(5 \mu \mathrm{m}) 3.3 \mathrm{~cm} \times \\
4.6 \mathrm{~mm}\end{array}$ & $\begin{array}{l}\text { Ascentis Express C18 } \\
(2.1 \mathrm{~mm} \times 10 \mathrm{~cm}, 2.7 \mu \mathrm{m} \\
\text { particles }) \text { column and } \\
\mathrm{C} 18(2.1 \times 5 \mathrm{~mm}, 2.7 \mu \mathrm{m} \\
\text { particles }) \text { guard column }\end{array}$ & $\begin{array}{l}\text { YMC-Pack Pro C18 RS } \\
(5 \mu \mathrm{m}, 8 \mathrm{~nm}) 150 \mathrm{~mm} \times 4.6 \\
\mathrm{~mm}\end{array}$ \\
\hline HPLC separation & $\begin{array}{l}\text { mobile phase: (1) } 0.1 \% \\
\text { formic acid, } 20 \% \mathrm{MeOH} \\
\text { in ultrapure water; (2) } 0.1 \\
\% \text { formic acid in methanol }\end{array}$ & $\begin{array}{l}\text { mobile phase: (1) } 45 \% \\
\mathrm{ACN} / 55 \% \mathrm{H}_{2} \mathrm{O} ;(2) \\
\text { methanol, both with } 2 \mathrm{mM} \\
\text { ammonium acetate and } \\
0.04 \% \text { formic acid }\end{array}$ & $\begin{array}{l}\text { mobile phase: } \\
\text { methanol/acetonitrile/wat } \\
\text { er }(48.5 / 48.5 / 3)\end{array}$ & $\begin{array}{l}\text { mobile phase: (1) Milli-Q } \\
\text { water, methylamine (5 } \\
\mathrm{mM}) \text {, and formic acid }(0.1 \\
\%) \text {; ( } 2 \text { ) methanol, } \\
\text { methylamine }(5 \mathrm{mM}) \text {, and } \\
\text { formic acid } 0.1 \%\end{array}$ & $\begin{array}{l}\text { mobile phase: (1) water, } \\
\text { (2) methanol }\end{array}$ \\
\hline Quantification & $\begin{array}{l}4000 \text { LC-MS/MS System } \\
\text { (Sciex): triple quadrupole } \\
\text { tandem mass } \\
\text { spectrometer }\end{array}$ & $\begin{array}{l}\text { LC-Agilent } 1100 \text { with } \\
\text { binary pump coupled to a } \\
\text { WATERS Quattro } \\
\text { Premier XE MSMS } \\
\text { system (ESi mode) }\end{array}$ & $\begin{array}{l}\text { Agilent } 1290 \text { UHPLC } \\
\text { system coupled to an } \\
\text { Agilent } 6460 \text { triple } \\
\text { quadrupole LC/MS/MS } \\
\text { ESI operated in positive } \\
\text { MRM mode }\end{array}$ & $\begin{array}{l}\text { Agilent } 1200 \text { series HPLC } \\
\text { coupled to an Agilent } \\
6460 \text { series triple } \\
\text { quadrupole mass } \\
\text { spectrometer operated in } \\
\text { positive MRM mode }\end{array}$ & $\begin{array}{l}\text { Agilent } 6410 \mathrm{~B} \text { MS/MS } \\
\text { system, APCI, positive } \\
\text { ionization mode }\end{array}$ \\
\hline Ion Masses ${ }^{a}$ & $\begin{array}{l}\mathrm{D}_{3} \\
560(383,298,280) \\
25(\mathrm{OH}) \mathrm{D}_{3} \\
558(298,280,247) \\
\mathrm{D}_{2} \\
572(298) \\
25(\mathrm{OH}) \mathrm{D}_{2} \\
\mathrm{~N} / \mathrm{A}\end{array}$ & $\begin{array}{l}\mathrm{D}_{3} \\
560(298,280) \\
25(\mathrm{OH}) \mathrm{D}_{3} \\
593(298,280) \\
\mathrm{D}_{2} \\
572(298,280) \\
25(\mathrm{OH}) \mathrm{D}_{2} \\
605(298,280)\end{array}$ & $\begin{array}{l}\mathrm{D}_{3} \\
385(367,259) \\
25(\mathrm{OH}) \mathrm{D}_{3} \\
401(383,365) \\
\mathrm{D}_{2} \\
397(379,107) \\
25(\mathrm{OH}) \mathrm{D}_{2} \\
413(395,355)\end{array}$ & $\begin{array}{l}\mathrm{D}_{3} \\
591(298) \\
25(\mathrm{OH}) \mathrm{D}_{3} \\
607(298) \\
\mathrm{D}_{2} \\
603(298) \\
25(\mathrm{OH}) \mathrm{D}_{2} \\
619(298)\end{array}$ & $\begin{array}{l}\mathrm{D}_{3}- \\
560(298) \\
25(\mathrm{OH}) \mathrm{D}_{3} \\
558(298) \\
\mathrm{D}_{2} \\
572(298) \\
25(\mathrm{OH}) \mathrm{D}_{2} \\
570(298)\end{array}$ \\
\hline $\begin{array}{l}\text { Limit of } \\
\text { quantification }\end{array}$ & $\begin{array}{l}\text { Vitamin } D_{3} / D_{2}: 0.05 / 0.20 \\
\mu g / 100 \mathrm{~g} ; 25(\mathrm{OH}) D_{3}: \\
0.012 \mu \mathrm{g} / 100 \mathrm{~g}\end{array}$ & $\begin{array}{l}\text { high moisture: } 0.08 \mathrm{ng} / \mathrm{g} \\
\text { low moisture: } 0.2 \mathrm{ng} / \mathrm{g}\end{array}$ & $0.5 \mathrm{ng} / \mathrm{g}$ & $<0.1 \mathrm{ng} / \mathrm{g}$ & $\begin{array}{l}\text { vitamin } D_{3} / D_{2}: 0.4 / 0.3 \\
\mathrm{ng} / \mathrm{g} \\
25(\mathrm{OH}) \mathrm{D}_{3} / \mathrm{D}_{2}: 0.2 / 0.7 \\
\mathrm{ng} / \mathrm{g}\end{array}$ \\
\hline
\end{tabular}

${ }^{a}$ Masses in parentheses are the product ions. ${ }^{b}$ Abbreviations: HPLC, high-performance liquid chromatography; SPE, solid-phase extraction; PTAD, 4-phenyl-1,2,4-triazole-3,5-dione; ACN, acetonitrile; UHPLC, ultrahigh-performance liquid chromatography; MS/MS, tandem mass spectrometry; $\mathrm{ESi}$, electrospray ionization; MRM, multiple reaction monitoring. 
Table 1b. Methodology for Analysis of Vitamin $D_{3}$ Content in the Dietary Supplement ${ }^{a}$

\begin{tabular}{|c|c|c|}
\hline & Laboratory A & Laboratory B \\
\hline Subsampling & fill from 30 softgels & 30 softgels dissolved in $20 \mathrm{~mL}$ of water at $50^{\circ} \mathrm{C}$ \\
\hline Internal standard & none & $\left({ }^{2} \mathrm{H}_{6}\right)$ vitamin $\mathrm{D}_{3}$ (Chemaphor, Ottawa, Canada) \\
\hline Initial treatment & none & $\begin{array}{l}20 \mathrm{~mL} \text { water at } 50{ }^{\circ} \mathrm{C} ; 70 \mathrm{~mL} 1 \% \text { pyrogallol in } \\
\text { ethanol added, followed by } 50 \mathrm{~mL} \mathrm{KOH} 60 \% \\
(\mathrm{w} / \mathrm{v})\end{array}$ \\
\hline Saponification & none & at room temperature overnight under $\mathrm{N}_{2}$ \\
\hline Extraction step & $\begin{array}{l}\text { weighed and dissolved in } \\
\text { hexane }\end{array}$ & $\begin{array}{l}\text { further extraction of an aliquot of the solution } \\
\text { using } 3 x \text { petroleum ether/diethyl ether }(80 / 20)\end{array}$ \\
\hline Clean-up step & & $\begin{array}{l}\text { organic phase is washed with water before } \\
\text { evaporation to dryness, dissolution of residue in } \\
2.0 \mathrm{~mL} \mathrm{1-chlorobutane}\end{array}$ \\
\hline Additional clean-up & & $\begin{array}{l}\text { purification using HPLC normal phase (silica } \\
\text { column) and fractions collection, evaporation of } \\
\text { fraction evaporated reconstitution in } \mathrm{MeOH}\end{array}$ \\
\hline HPLC column & $\begin{array}{l}\text { Partisil }(250 \mathrm{~mm} \times 4.6 \\
\mathrm{mm}), 5 \text { micron }\end{array}$ & ACE-C18 3.0um, $150 \times 3.0 \mathrm{~mm}$ \\
\hline HPLC separation & $\begin{array}{l}\text { mobile phase: (1)1.5 \% } \\
\text { isopropanol/hexane; (2) } 5 \\
\% \text { isopropanol/hexane }\end{array}$ & $\begin{array}{l}\text { mobile phase: (1) } 50 \% \text { methanol } / \mathrm{H}_{2} \mathrm{O}+0.1 \% \\
\text { acetic acid; (2) methanol } 95 \%+\text { isopropanol } 5 \\
\%+0.1 \% \text { acetic acid }\end{array}$ \\
\hline Quantification & $\begin{array}{l}\text { HPLC-UV detection at } 265 \\
\mathrm{~nm}\end{array}$ & $\begin{array}{l}\text { LC-MS/MS APCi Agilent } 1100 \text { LC coupled to a } \\
\text { Thermo Quantum Ultra triple quad MS/MS }\end{array}$ \\
\hline $\begin{array}{l}\text { Limit of } \\
\text { quantification }\end{array}$ & $0.05 \mu \mathrm{g} / 100 \mathrm{~g}$ & $700 \mu \mathrm{g} / 100 \mathrm{~g}$ vitamin $D_{3}$ \\
\hline
\end{tabular}

10 softgels dissolved

methanolic $\mathrm{KOH}$

2 hours at $60^{\circ} \mathrm{C}$

$3 x$ hexane/ethyl acetate $(85 / 15)$

dried and redissolved in $1 \mathrm{~mL}$ hexane/methylene chloride

loaded into an SPE cartridge, eluted with methylene chloride/isopropanol, two clean-ups through HPLC columns

Supelco-Sil LC-18 ODS column

mobile phase:

methanol/acetonitrile/water (48.5/48.5/3)

HPLC-UV with liquid scintillation counting for internal standard

$5 \mathrm{ng}$ by ratio of weight to calculated concentration

${ }^{a}$ Abbreviations: HPLC, high-performance liquid chromatography; SPE, solid-phase extraction; UV, ultraviolet; LC-MS/MS, liquid chromatographytandem mass spectrometry; APCi, atmospheric pressure chemical ionization.

might affect extraction and quantitation [e.g., fat content, concentration of vitamin $\mathrm{D}_{3}$, and $25(\mathrm{OH}) \mathrm{D}_{3}$, and animal tissue type (e.g., muscle, liver, or egg)].

Selection of the DS. The DS product for this study was selected with the aim of developing a DS in-house control material. Scientists on the Dietary Supplement Ingredient Database team at NDL studied current vitamin $\mathrm{D}_{3}$ supplements on the market, evaluating claimed composition and manufacturing information for both animal- and nonanimal-based vitamin $\mathrm{D}_{3}$ supplements (Supplemental Table 1). Their goal was to purchase supplements that represented a diversity of vitamin $\mathrm{D}$ source materials, production methods, matrices, and supplement strength (vitamin $\mathrm{D}_{3}$ labeled content) and test them for $25(\mathrm{OH}) \mathrm{D}_{3}$ content. On the basis of these criteria, six products sold as capsules, tablets, softgels, and powder labeled as having vitamin $\mathrm{D}_{3}$ content and one product labeled as having $25(\mathrm{OH}) \mathrm{D}_{3}$ content were chosen for preliminary analyses. These products had a wide range of labeled vitamin $\mathrm{D}$ content per serving (from 0 to $12,500 \mathrm{IU}$ ). Subsamples of 90 units of each product were placed in amber plastic bottles with desiccant packs, sealed under ambient conditions, and shipped via next-day delivery to Covance Laboratories for screening analysis of vitamin $\mathrm{D}_{3}$ and $25(\mathrm{OH}) \mathrm{D}_{3}$ content.

The screening results (presented in Supplemental Table 2) also indicated that all six DS products sold with vitamin $\mathrm{D}_{3}$ content claims contained $25(\mathrm{OH}) \mathrm{D}_{3}$ at levels similar to those in the foods tested for inclusion in the study. However, their $25(\mathrm{OH}) \mathrm{D}_{3}$ levels were minute compared to the amount of vitamin $\mathrm{D}_{3}$ in the products. The label of the product ultimately chosen for the study claimed that it contained $2000 \mathrm{IU}$ vitamin $\mathrm{D}_{3}$ /serving, a level commonly taken by the U.S. population. This product also contained a measurable amount of $25(\mathrm{OH}) \mathrm{D}_{3}$. It was a private-brand softgel capsule sold in warehouse stores and was produced using a common manufacturing process of lanolin recrystallization. ${ }^{31}$ Thus, purchasing this product by the case provided a large amount of serving units of the same lot, enabling its use as an in-house control material in future studies.

Sample Preparation and Shipment. Separate sample sets of the selected materials were shipped to each laboratory on two occasions (hereafter referred to as "trial 1" and "trial 2") separated by approximately 2 months. The NIST materials were shipped in their original packaging. The DS for the study was stored at $-30{ }^{\circ} \mathrm{C}$ in its original containers, and individual bottles were opened only as needed. Each shipment included a total of 40-100 g of material per food and 90 DS softgel capsules. Sample bottle labels identified the material type. The samples were shipped on dry ice in an insulated cooler via express overnight delivery to each laboratory. General estimates of the expected concentrations of vitamin $\mathrm{D}_{3}$ and $25(\mathrm{OH}) \mathrm{D}_{3}$ in each sample were given to the laboratories to assist in determining the assay parameters.

Sample Analysis. The laboratories were asked to use their usual methodology to analyze vitamin $\mathrm{D}$ in duplicate or triplicate in each sample. Although results for vitamin $\mathrm{D}_{2}$ were not requested, some laboratories also included vitamin $\mathrm{D}_{2}$ in their assays. All laboratories spectroscopically characterized their standards before use; the only materials supplied to the laboratories were the samples to be analyzed. Laboratories were asked to describe their methodology in detail and to answer a set of questions on the analyses that they performed. For the DS, the laboratories were advised to combine 30 units (i.e., capsules, tablets, softgels) for each assay. (U.S. Pharmacopeia provides guidelines on the amounts of capsules or tablets to be combined for analysis that range from at least 10 to at least 30 for products with vitamin D only or with vitamin D in multivitamin matrices. ${ }^{32-34}$ ) Guidelines for subsampling the DS were provided. The guidelines indicated that each laboratory had the option to analyze for each replicate assay the contents (fill only) of the combined 30 softgels or to dissolve 30 whole softgels before subsampling and analysis. Laboratories that conducted their analyses after dissolving the whole softgels calculated results for the amount of fill based on the weights of the whole capsules and their fill. Thus, for this paper, DS concentrations from all laboratories are reported as micrograms per $100 \mathrm{~g}$ of fill contents.

Data Review. Each laboratory's trial 1 data report was reviewed by an internal NDL group to ensure that all required information was received and to detect any potential problems with analyses, such as deviations from the study protocol or major discrepancies in results. NDL contacted laboratories that had report deviations or discrep- 
ancies to alert them of any nonrepresentative analytical errors before these laboratories analyzed the second set of samples. Trial 2 data sets were also reviewed by an internal NDL group.

Statistical Methods. Results for each material included the replicate values for both trials from all laboratories. Data analysis was performed using PROLAB Plus software (QuoData Quality \& Statistics, Dresden, Germany). Analyses included calculations of reproducibility relative standard deviations (RSDs) and repeatability RSDs for each material according to ISO $5725-2 .{ }^{35}$ The reproducibility RSD expresses the precision of the average of the results from different laboratories and was calculated using the SD between the averages of replicate measurements by each laboratory in each trial. On the basis of the probability of detection (POD) model, predicted reproducibility RSD is calculated as $2 \times C^{-0.15}$, where $C$ is a mass fraction of analyte, and estimated RSD is expressed as percent. Predicted repeatability RSD is considered to be half of this value. As the concentration decreases, the POD decreases and predicted RSD increases, as illustrated by the Horwitz curve. ${ }^{36,37}$

The repeatability RSD for each material expresses the variability between independent test results obtained within each laboratory. In this study, the repeatability RSD was calculated using the SD between the replicate measurements of each laboratory within each trial (the square root of the sum of the squares of the within-laboratory SD divided by 2 , followed by multiplication by the number of laboratory/ trials) as an estimate of overall within-laboratory variability for each analyte in each sample.

The Horwitz ratio (HorRat) was used to evaluate the reproducibility RSDs from data provided by the different laboratories for the materials. ${ }^{37,38}$ The HorRat indicates the acceptability of the reproducibility of interlaboratory measurements, taking into consideration the analyte concentration. This ratio is the RSD of the mean divided by a predicted reproducibility RSD based on the concentration of the analyte. An acceptable HorRat is $\leq 2.0 .^{37}$

Outliers were identified using the Cochran test (analysis of variance) and Grubbs test (analysis of mean value deviations) according to ISO 5725-2. ${ }^{35}$ Because the purpose of this study was to evaluate both inter- and intralaboratory variability for each material, the outliers identified from these tests were not excluded from calculation of overall mean and SD. One exception, however, was a value identified as an outlier by the Grubbs test that had already been manually excluded as a result of the analyst's data evaluation (laboratory D's vitamin $\mathrm{D}_{3}$ measurement of the meat homogenate in trial 1). This outlier is explained under Results.

\section{RESULTS}

Analytical Methods Used for Foods. After receipt of trial 1 data, it was evident that results from laboratory E differed markedly from those of the other laboratories. Laboratory E was not given details on the results from the other laboratories. However, because this laboratory had experience primarily in determining vitamin $\mathrm{D}$ and $25(\mathrm{OH}) \mathrm{D}$ levels in serum, the laboratory optimized its method to measure these analytes in food matrices before analyzing additional study samples. A new set of samples was then sent to laboratory E, which reported values for the meat homogenate, ground beef, and liver samples. Laboratories A, B, C, and E analyzed each food material in triplicate (three subsamples from the same mixture on the same day), and laboratory D submitted duplicate data.

Table la summarizes the methodology used by each laboratory. All laboratories used LC-MS/MS to quantify vitamin $\mathrm{D}_{3}$ and $25(\mathrm{OH}) \mathrm{D}_{3}$ levels without using a common sample preparation protocol. The laboratories labeled their internal standards in varied ways as well, using, for example, deuterium, tritium, or carbon-13. All laboratories calibrated their standards before use, which is important for obtaining accurate results. They also optimized their methodologies to measure the low concentrations of $25(\mathrm{OH}) \mathrm{D}$ in the foods and
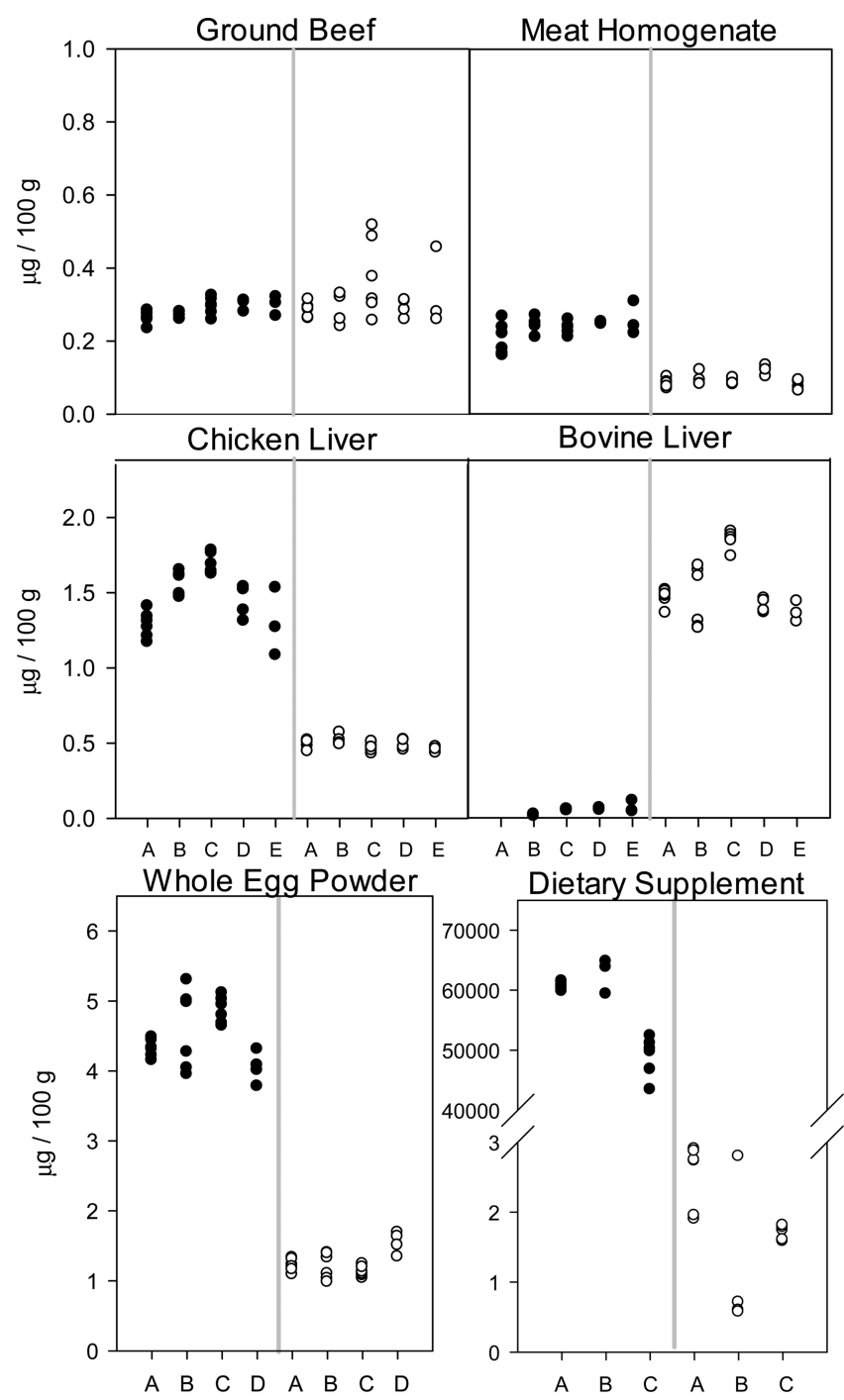

Figure 1. Results for analyses of vitamin $\mathrm{D}_{3}$ and $25(\mathrm{OH}) \mathrm{D}_{3}(\mu \mathrm{g} / 100$ g) levels in six matrices in two trials from five laboratories (A-E): (O) vitamin $\mathrm{D}_{3} ;(\mathrm{O}) 25(\mathrm{OH}) \mathrm{D}_{3}$.

DS and of vitamin D in the foods. Laboratories A, B, D, and E derivatized the samples prior to LC-MS/MS analysis, but laboratory $\mathrm{C}$ did not. Another significant difference was that laboratory $\mathrm{E}$ did not saponify the samples but used an enzymatic digestion with lipase prior to LC-MS/MS analysis. Laboratory $\mathrm{E}$ indicated that its method had not been sufficiently validated for eggs and supplements, so it did not report results for those materials. In addition, laboratory D's analyst indicated concern about the validity of the vitamin $\mathrm{D}_{3}$ value for the meat homogenate when reporting its trial 1 results. Therefore, laboratory D's data were excluded from these study results.

Analytical Methods Used for the DS. The DS was analyzed by laboratories $\mathrm{A}, \mathrm{B}$, and $\mathrm{C}$ (Tables $1 \mathrm{a}$ and $1 \mathrm{~b}$ ). Laboratory A analyzed the fill contents, whereas laboratories B and $C$ analyzed whole softgels. Laboratories A and C analyzed the DS in triplicate. Laboratory B submitted one value for trial 1 and values from duplicate analysis for trial 2 . Laboratory $\mathrm{C}$ conducted both of its trials for $25(\mathrm{OH}) \mathrm{D}_{3}$ on the same day, rather than 2 months apart. Because laboratory $\mathrm{C}$ used a separate set of material and assay batches for each sample set, the data are reported here for two separate trials, even though 
Table 2a. Vitamin $\mathrm{D}_{3}$ and $25(\mathrm{OH}) \mathrm{D}_{3}$ in Food Samples Analyzed by Five Participating Laboratories ${ }^{a, b}$

\begin{tabular}{|c|c|c|c|c|c|c|c|c|c|c|c|c|}
\hline & \multicolumn{6}{|c|}{ mean vitamin $D_{3}(\mu \mathrm{g} / 100 \mathrm{~g})$} & \multicolumn{6}{|c|}{ mean $25(\mathrm{OH}) \mathrm{D}_{3}(\mu \mathrm{g} / 100 \mathrm{~g})$} \\
\hline & $\begin{array}{l}\text { chicken } \\
\text { liver }\end{array}$ & $\begin{array}{l}\text { dried } \\
\text { bovine } \\
\text { liver } \\
\text { (NIST } \\
\text { 1577c) }\end{array}$ & $\begin{array}{l}\text { whole } \\
\text { egg } \\
\text { powder } \\
\text { (NIST } \\
\text { 1845a) }\end{array}$ & $\begin{array}{l}\text { ground } \\
\text { beef }\end{array}$ & $\begin{array}{c}\text { meat } \\
\text { homogen } \\
\text {-ate } \\
\text { (NIST } \\
1546 \mathrm{a})\end{array}$ & $\begin{array}{c}\text { dietary } \\
\text { supplement } \\
\text { (fill only) }\end{array}$ & $\begin{array}{l}\text { chicken } \\
\text { liver }\end{array}$ & $\begin{array}{c}\text { dried } \\
\text { bovine } \\
\text { liver } \\
\text { (NIST } \\
\text { 1577c) }\end{array}$ & $\begin{array}{c}\text { whole } \\
\text { egg } \\
\text { powder } \\
\text { (NIST } \\
\text { 1845a) }\end{array}$ & $\begin{array}{c}\text { ground } \\
\text { beef }\end{array}$ & $\begin{array}{c}\text { meat } \\
\text { homogen } \\
\text {-ate } \\
\text { (NIST } \\
1546 a)\end{array}$ & $\begin{array}{l}\text { dietary } \\
\text { supplement } \\
\text { (fill only) }\end{array}$ \\
\hline \multicolumn{13}{|l|}{ Trial 1} \\
\hline Laboratory A & 1.35 & $<0.05^{c}$ & 4.42 & 0.28 & 0.24 & 61200 & 0.48 & 1.42 & 1.29 & 0.28 & 0.09 & 2.79 \\
\hline Laboratory B & 1.63 & 0.016 & 5.10 & 0.27 & 0.257 & 59357 & 0.57 & 1.62 & 1.37 & 0.33 & 0.12 & 1.75 \\
\hline Laboratory C & 1.65 & 0.05 & 5.03 & 0.31 & 0.23 & 51256 & 0.50 & 1.81 & 1.12 & 0.29 & 0.09 & $1.78^{d}$ \\
\hline Laboratory D & 1.46 & 0.06 & 4.20 & 0.31 & e & & 0.46 & 1.39 & 1.66 & 0.27 & 0.11 & \\
\hline \multicolumn{13}{|l|}{ Trial 2} \\
\hline Laboratory A & 1.22 & $<0.05^{c}$ & 4.23 & 0.25 & 0.17 & 60200 & 0.52 & 1.46 & 1.15 & 0.29 & 0.08 & 2.24 \\
\hline Laboratory B & 1.48 & 0.014 & 4.09 & 0.28 & 0.23 & 64280 & 0.50 & 1.26 & 1.04 & 0.25 & 0.09 & 0.58 \\
\hline Laboratory C & 1.72 & 0.05 & 4.71 & 0.28 & 0.24 & 46653 & 0.45 & 1.83 & 1.14 & 0.46 & 0.08 & $1.66^{e}$ \\
\hline Laboratory D & 1.42 & 0.05 & 3.90 & 0.29 & 0.25 & & 0.52 & 1.39 & 1.46 & 0.31 & 0.13 & \\
\hline Laboratory E & 1.29 & 0.07 & & 0.30 & 0.26 & & 0.46 & 1.34 & & 0.33 & 0.08 & \\
\hline \multicolumn{13}{|l|}{ combined } \\
\hline mean & 1.47 & 0.043 & 4.49 & 0.284 & 0.233 & 56390 & 0.495 & 1.51 & 1.25 & 0.315 & 0.093 & 1.82 \\
\hline SD & 0.20 & 0.025 & 0.45 & 0.023 & 0.034 & 7160 & 0.041 & 0.21 & 0.20 & 0.074 & 0.019 & 0.82 \\
\hline $\begin{array}{l}\text { reproducibility } \\
\% \text { RSD }\end{array}$ & 13.3 & 58.0 & 10.0 & 8.0 & 14.8 & 12.7 & 8.3 & 14.1 & 16.0 & 23.5 & 20.7 & 45.1 \\
\hline Horwitz ratio & 0.4 & 1.1 & 0.4 & 0.2 & 0.4 & 2.1 & 0.2 & 0.5 & 0.5 & 0.6 & 0.5 & 1.6 \\
\hline $\begin{array}{c}\text { repeatability \% } \\
\text { RSD }\end{array}$ & 6.9 & 38.7 & 2.8 & 6.2 & 9.7 & 2.9 & 3.4 & 3.6 & 5.4 & 15.6 & 10.6 & 14.8 \\
\hline
\end{tabular}

${ }^{a}$ Shaded cells indicate no data reported. ${ }^{b}$ Values for foods in this table are means from triplicate analyses within each trial reported by laboratories A, $\mathrm{B}, \mathrm{C}$, and $\mathrm{E}$ and duplicate analyses from laboratory D. Abbreviations: NIST, National Institute of Standards and Technology (Gaithersburg, MD, USA); SD, standard deviation; RSD, relative standard deviation. ${ }^{c}$ Laboratory A reported a vitamin $\mathrm{D}_{3}$ level of $<0.05$ for dried bovine liver (NIST $1577 \mathrm{c}$ ) in trials 1 and 2, which is lower than the laboratory's limit of quantification. Therefore, these values were omitted from mean and SD calculations. ${ }^{d}$ Laboratory $\mathrm{C}$ conducted both of its trials on the same day, not 2 months apart as the other laboratories did. ${ }^{e}$ Laboratory D indicated uncertainty about the quality of its data on meat homogenate (NIST 1546a). Therefore, this value was considered an outlier and excluded from the results reported here.

the assays were not separated in time as was the case at the other laboratories. Because the $25(\mathrm{OH}) \mathrm{D}_{3}$ content of the DS was similar to that of the foods, the laboratories measured it as described in Table 1a. The DS's vitamin $\mathrm{D}_{3}$ content was orders of magnitude higher than its $25(\mathrm{OH}) \mathrm{D}_{3}$ content and the vitamin $\mathrm{D}_{3}$ in foods. As a result the laboratories optimized their methodologies to measure the high levels of vitamin $\mathrm{D}_{3}$ in the DS (Table 1b). Laboratory B used LC-MS/MS to measure vitamin $\mathrm{D}_{3}$ but did not derivatize the sample (because it is not necessary for high levels), whereas laboratories A and C used high-performance liquid chromatography-UV (a less sensitive detection method).

Vitamin $D_{3}$ and 25(OH) $D_{3}$ Results for the Food Materials. Figure 1 and Table 2 a summarize the results for vitamin $\mathrm{D}_{3}$ and $25(\mathrm{OH}) \mathrm{D}_{3}$ levels in the foods analyzed. The mean assayed vitamin $\mathrm{D}_{3}$ concentrations ranged from 0.043 $\mu \mathrm{g} / 100 \mathrm{~g}$ (dried bovine liver) to $4.49 \mu \mathrm{g} / 100 \mathrm{~g}$ (whole egg powder). The mean vitamin $\mathrm{D}_{3}$ levels in the meat homogenate, whole egg powder, and chicken liver were higher than the corresponding $25(\mathrm{OH}) \mathrm{D}_{3}$ levels in these foods, and the $25(\mathrm{OH}) \mathrm{D}_{3}$ levels were higher than the vitamin $\mathrm{D}_{3}$ levels in the dried bovine liver and ground beef.

The mean assayed $25(\mathrm{OH}) \mathrm{D}_{3}$ concentrations ranged from $0.093 \mu \mathrm{g} / 100 \mathrm{~g}$ (meat homogenate) to $1.51 \mu \mathrm{g} / 100 \mathrm{~g}$ (dried bovine liver). Dried bovine liver had the lowest vitamin $\mathrm{D}_{3}$ content of all materials analyzed $(0.043 \mu \mathrm{g} / 100 \mathrm{~g})$, near the limit of quantitation for all of the laboratories. However, dried bovine liver had the highest $25(\mathrm{OH}) \mathrm{D}_{3}$ content $(1.51 \mu \mathrm{g} / 100$ g) of the food materials.
The reproducibility for vitamin $\mathrm{D}_{3}$ ranged from $8 \%$ (ground beef) to 58\% RSD (dried bovine liver; predicted reproducibility RSD for this very low analyte concentration is $51.28 \%$ ). The corresponding HorRat values were all acceptable, ranging from 0.2 to 1.1 . Repeatability for vitamin $\mathrm{D}_{3}$ ranged from $2.8 \%$ RSD (whole egg powder) to $38.7 \%$ RSD (dried bovine liver; predicted repeatability RSD for this low analyte concentration is $25.64 \%$, Table $2 \mathrm{a}$ ).

The reproducibility for $25(\mathrm{OH}) \mathrm{D}_{3}$ ranged from $8.3 \% \mathrm{RSD}$ (chicken liver) to $23.5 \%$ RSD (ground beef). The HorRat values ranged from 0.2 (chicken liver) to 0.6 (ground beef). Repeatability for $25(\mathrm{OH}) \mathrm{D}_{3}$ ranged from $3.4 \%$ RSD (chicken liver) to $15.6 \%$ RSD (ground beef; Table $2 \mathrm{a}$ ).

Vitamin $\mathrm{D}_{3}$ and $25(\mathrm{OH}) \mathrm{D}_{3}$ Results for the DS. The mean assayed concentration of vitamin $\mathrm{D}_{3}$ in the DS was $56,400 \mu \mathrm{g} /$ $100 \mathrm{~g}$. The mean $25(\mathrm{OH}) \mathrm{D}_{3}$ value was $1.82 \mu \mathrm{g} / 100 \mathrm{~g}$, which was comparable to the levels found in the foods. The mean vitamin $\mathrm{D}_{3}$ amount for the $\mathrm{DS}$ in this study was $14.8 \%$ above the labeled level [\% difference for screened supplements ranged from 10.8 to $57.5 \%$ (see Supplemental Table 2)]. Reproducibility was $12.7 \%$ RSD for vitamin $\mathrm{D}_{3}$ and $45.1 \%$ RSD for $25(\mathrm{OH}) \mathrm{D}_{3}$. Repeatability was $2.9 \% \mathrm{RSD}$ for vitamin $\mathrm{D}_{3}$ and $14.8 \%$ RSD for $25(\mathrm{OH}) \mathrm{D}_{3}$. For comparison, predicted reproducibility and repeatability RSDs for $25(\mathrm{OH}) \mathrm{D}_{3}$ were 40.93 and $20.46 \%$, respectively. However, the three laboratories handled the DS differently. Two laboratories dissolved the capsules and provided the data in micrograms per $100 \mathrm{~g}$ (whole capsule). The other laboratory cut the capsules open, emptied the contents, and provided the data in micrograms per $100 \mathrm{~g}$ of 
Table $2 b$. Vitamin $\mathrm{D}_{2}$ and $25(\mathrm{OH}) \mathrm{D}_{2}$ in Dried Bovine Liver and Ground Beef Measured by Three Participating Laboratories $^{a, b}$

\begin{tabular}{|c|c|c|c|c|}
\hline & \multicolumn{2}{|c|}{$\begin{array}{l}\text { mean Vitamin } D_{2} \\
(\mu \mathrm{g} / 100 \mathrm{~g})\end{array}$} & \multicolumn{2}{|c|}{$\begin{array}{c}\text { mean } \\
25(\mathrm{OH}) \mathrm{D}_{2} \\
(\mu \mathrm{g} / 100 \mathrm{~g})\end{array}$} \\
\hline & $\begin{array}{l}\text { dried } \\
\text { bovine } \\
\text { liver } \\
\text { (NIST } \\
1577 \mathrm{c} \text { ) }\end{array}$ & $\begin{array}{l}\text { ground } \\
\text { beef }\end{array}$ & $\begin{array}{c}\text { dried } \\
\text { bovine } \\
\text { liver } \\
\text { (NIST } \\
\text { 1577c) }\end{array}$ & $\begin{array}{l}\text { ground } \\
\text { beef }\end{array}$ \\
\hline \multicolumn{5}{|l|}{ Trial 1} \\
\hline \multirow{2}{*}{$\begin{array}{l}\text { Laboratory B } \\
\text { Laboratory D }\end{array}$} & $<0.01$ & 0.071 & 0.08 & 0.072 \\
\hline & & 0.067 & 0.053 & 0.0435 \\
\hline \multicolumn{5}{|l|}{ Trial 2} \\
\hline Laboratory B & $<0.03$ & 0.078 & 0.07 & 0.073 \\
\hline Laboratory D & & 0.055 & 0.040 & 0.044 \\
\hline Laboratory E & 0.033 & 0.184 & 0.063 & 0.090 \\
\hline \multicolumn{5}{|l|}{ combined } \\
\hline mean & & 0.099 & 0.064 & 0.067 \\
\hline SD & & 0.058 & 0.015 & 0.024 \\
\hline $\begin{array}{l}\text { reproducibility\% } \\
\text { RSD }\end{array}$ & & 59.0 & 24.2 & 35.2 \\
\hline Horwitz ratio & & 1.3 & 0.5 & 0.7 \\
\hline $\begin{array}{l}\text { repeatability \% } \\
\text { RSD }\end{array}$ & 27.6 & 22.3 & 13.4 & 22.7 \\
\hline
\end{tabular}

${ }^{a}$ Shaded cells indicate no data reported or not applicable. ${ }^{b}$ Values for foods in this table represent means from triplicate analyses within trials reported by laboratories $\mathrm{B}$ and $\mathrm{E}$ and duplicate analyses from laboratory D. Abbreviations: NIST, National Institute of Standards and Technology (Gaithersburg, MD, USA); < , value below laboratory's limit of quantitation; SD, standard deviation; RSD, relative standard deviation.

fill as well as the total weights of the fill and capsule shell. The weight data were applied to the first laboratory's results to calculate the results in micrograms per $100 \mathrm{~g}$ of fill for direct comparison. For the DS results reported based on fill weight, the HorRat values were 2.1 for vitamin $\mathrm{D}_{3}$ and 1.6 for $25(\mathrm{OH}) \mathrm{D}_{3}$ (see Table 2a). The HorRat values for the DS results based on the weight of the whole capsule were 1.8 and 1.3, respectively (see Supplemental Table 3).

Vitamin $D_{2}$ and $25(O H) D_{2}$ Results for the Foods and DS. Only three laboratories reported results for vitamin $\mathrm{D}_{2}$ and $25(\mathrm{OH}) \mathrm{D}_{2}$ levels, and only laboratory $\mathrm{B}$ reported values for vitamin $\mathrm{D}_{2}$ and $25(\mathrm{OH}) \mathrm{D}_{2}$ in all materials. Therefore, results for vitamin $\mathrm{D}_{2}$ and $25(\mathrm{OH}) \mathrm{D}_{2}$ are provided for descriptive purposes only, and only values above the limit of quantification are reported (Table $2 \mathrm{~b}$ ). The vitamin $\mathrm{D}_{2}$ level reported by laboratory $\mathrm{B}$ was below the limit of quantitation in all materials except ground beef, and $25(\mathrm{OH}) \mathrm{D}_{2}$ was measurable only in ground beef and dried bovine liver. The vitamin $\mathrm{D}_{2}$ and $25(\mathrm{OH}) \mathrm{D}_{2}$ levels reported by laboratory $\mathrm{B}$ were considerably lower than those of vitamin $\mathrm{D}_{3}$ and $25(\mathrm{OH}) \mathrm{D}_{3}(<0.1 \mu \mathrm{g} / 100$ g).

\section{DISCUSSION}

For the foods in this study, the HorRat values for vitamin $\mathrm{D}_{3}$ and $25(\mathrm{OH}) \mathrm{D}_{3}$ (ranging from 0.2 to 1.1 ) demonstrated acceptable between-laboratory reproducibility at the analyte concentration present for all of the matrices (ground beef, chicken liver, whole egg powder, meat homogenate, and dried bovine liver). In our study, the low repeatability RSDs for vitamin $\mathrm{D}_{3}$ and for $25(\mathrm{OH}) \mathrm{D}_{3}$, seen in all of the matrices except vitamin $\mathrm{D}_{3}$ in bovine liver, suggest that the laboratories had consistent within-laboratory results and, thus, acceptable within-laboratory precision for all study materials. Therefore, our study shows that it is possible to obtain results with acceptable overall reproducibility among experienced laboratories using LC-MS/MS to measure levels of vitamin $\mathrm{D}_{3}$ and $25(\mathrm{OH}) \mathrm{D}_{3}$ for a variety of food matrices having naturally occurring vitamin $\mathrm{D}_{3}$ and $25(\mathrm{OH}) \mathrm{D}_{3}$.

For the DS, the three laboratories demonstrated that they were able to measure vitamin $\mathrm{D}_{3}$ at high levels as well as very low levels of $25(\mathrm{OH}) \mathrm{D}_{3}$. The HorRat values of 2.1 and 1.8 for vitamin $\mathrm{D}_{3}$ and 1.6 and 1.3 for $25(\mathrm{OH}) \mathrm{D}_{3}$ indicate acceptable or close to acceptable reproducibility relative to the analyte concentration. The elevated RSDs obtained experimentally are close to theoretically predicted RSDs at such low analyte concentrations, and this is reflected in acceptable HorRat ratios. For example, the \% RSD for the very low level $25(\mathrm{OH}) \mathrm{D}_{3}$ in bovine liver seems very high. However, it is an acceptable RSD because as the concentration decreases, the predicted RSD increases, as illustrated by the Horwitz curve. ${ }^{37}$

The amount of $25(\mathrm{OH}) \mathrm{D}_{3}$ in the vitamin $\mathrm{D}$ supplement was very low but was consistently present in all DSs analyzed in the screening and in the study. Vitamin D levels above label claims (overages) were seen in the DSs selected for this study and in the products screened for inclusion in this study. Manufacturers may add ingredient overages to provide the minimum content stated on the label at the end of the product shelf life. ${ }^{39}$

Vitamin $\mathrm{D}_{2}$ and $25(\mathrm{OH}) \mathrm{D}_{2}$ were found in small quantities in ground beef and bovine liver, with acceptable HorRat ratios, although our study's focus was on measuring vitamin $\mathrm{D}_{3}$ and $25(\mathrm{OH}) \mathrm{D}_{3}$. Future studies need to identify whether different samples of beef in the food supply have variable vitamin $D_{2}$ content and identify sources of vitamin $\mathrm{D}_{2}$ in food samples such as components of animals' diets.

The source of $25(\mathrm{OH}) \mathrm{D}_{3}$ in meat, poultry, and eggs could be due to the animal's exposure to UV light, resulting in in vivo production of vitamin $\mathrm{D}_{3}$, or derived from the animal's feed containing vitamin $\mathrm{D}_{3}$ or $25(\mathrm{OH}) \mathrm{D}_{3}$. Thus, variation in animal diet and environment can affect vitamin $\mathrm{D}_{3}$ and $25(\mathrm{OH}) \mathrm{D}_{3}$ levels in animal-based foods. ${ }^{21,40-48}$ Unfortunately, data on the $25(\mathrm{OH}) \mathrm{D}_{3}$ content of foods are limited and existing data can vary greatly. ${ }^{21,49,50}$

Comparison of studies of $25(\mathrm{OH}) \mathrm{D}_{3}$ in foods is hindered by the lack of relevant certified reference materials, ${ }^{51}$ which makes it difficult to ascertain whether the differences between studies are due to methodological or physiological factors. Matrixmatched reference or control samples make it possible to quantify the contribution of analytical differences that are separate from differences in food composition. Developing reference materials for use in analyses, for foods and for DSs, is relevant to ensuring the trueness of vitamin $\mathrm{D}_{3}$ and $25(\mathrm{OH}) \mathrm{D}_{3}$ estimates. The data from this study will be used to help assign reference values for vitamin $\mathrm{D}_{3}$ and $25(\mathrm{OH}) \mathrm{D}_{3}$ in several NIST SRMs-Bovine Liver (SRM 1577c), Meat Homogenate (SRM 1546a), and Whole Egg Powder (SRM 1845a). ${ }^{52}$ As for reference values for DSs, this study provided data on a vitamin $\mathrm{D}$ product that could be used as in-house control material in future studies.

Our study had several limitations. Because it included only experienced analysts, validated methods, and appropriate equipment to obtain results, we cannot draw conclusions about the likely performance of other laboratories in analyzing the same materials. We also did not seek to quantify any bias between laboratories. Although the overall reproducibility was 
acceptable for all materials, some systematic bias between laboratories could have affected the comparison of nutrient content results for foods analyzed at different laboratories.

Continued efforts to determine amounts of vitamin $\mathrm{D}$ and $25(\mathrm{OH}) \mathrm{D}$ in foods and supplements using validated methodologies and well-characterized control and reference materials will help answer questions about discrepancies between circulating amounts of $25(\mathrm{OH}) \mathrm{D}$ in the body and vitamin $\mathrm{D}$ intakes calculated from composition data for foods and DSs. These endeavors can also help ensure that public health policy decisions about vitamin $\mathrm{D}$ are based on accurate estimates of intake.

\section{ASSOCIATED CONTENT}

\section{S Supporting Information}

The Supporting Information is available free of charge on the ACS Publications website at DOI: 10.1021/acs.jafc.5b05016.

Descriptions and analytical results of seven dietary supplements screened for vitamin $\mathrm{D}_{3}$ and $25(\mathrm{OH}) \mathrm{D}_{3}$ and per-capsule analytical results from three laboratories for the dietary supplement (PDF)

\section{AUTHOR INFORMATION}

\section{Corresponding Author}

*(J.M.R.) E-mail: janet.roseland@ars.usda.gov. Phone (301) 504-0715. Fax: (301) 504-0632.

\section{Funding}

Partial funding for this work was provided under Agreement 60 12353012 from Office of Dietary Supplements of the National Institutes of Health.

\section{Notes}

Trade names are included for the reader's information only and are not meant to imply endorsement or preferential treatment by the U.S. government.

The authors declare no competing financial interest.

\section{ACKNOWLEDGMENTS}

We thank Covance, Heartland, Health Canada, Technical University of Denmark, and Virginia Tech laboratory personnel for their participation and significant contributions to this study. We also acknowledge the analysts for their expertise, including Carolyn Burdette from NIST. We thank Will Guthrie from NIST for his statistical advice on the intra- and interlaboratory results and Debby Berlyne for her professional editorial contributions.

\section{ABBREVIATIONS USED}

25(OH)D, 25-hydroxyvitamin D; DS, dietary supplement; USDA, U.S. Department of Agriculture; LC-MS/MS, liquid chromatography-tandem mass spectrometry; NDL, Nutrient Data Laboratory; NIST, National Institute of Standards and Technology; SRM, standard reference material; RSD, relative standard deviation; HorRat, Horwitz ratio

\section{REFERENCES}

(1) Grober, U.; Spitz, J.; Reichrath, J.; Kisters, K.; Holick, M. F. Vitamin D: Update 2013: from rickets prophylaxis to general preventive healthcare. Derm.-Endocrinol. 2013, 5, 331-347.

(2) Wacker, M.; Holick, M. F. Sunlight and vitamin D: a global perspective for health. Derm.-Endocrinol. 2013, 5, 51-108.
(3) Holick, M. F.; Chen, T. C. Vitamin D deficiency: a worldwide problem with health consequences. Am. J. Clin. Nutr. 2008, 87, 1080S-1086S.

(4) Au, L. E.; Rogers, G. T.; Harris, S. S.; Dwyer, J. T.; Jacques, P. F.; Sacheck, J. M. Associations of vitamin D intake with 25hydroxyvitamin $\mathrm{D}$ in overweight and racially/ethnically diverse US children. J. Acad. Nutr. Diet. 2013, 113, 1511-1516.

(5) Jacobs, E. T.; Alberts, D. S.; Benuzillo, J.; Hollis, B. W.; Thompson, P. A.; Martinez, M. E. Serum 25(OH)D levels, dietary intake of vitamin D, and colorectal adenoma recurrence. J. Steroid Biochem. Mol. Biol. 2007, 103, 752-756.

(6) Messenger, W.; Nielson, C. M.; Li, H.; Beer, T.; Barrett-Connor, E.; Stone, K.; Shannon, J. Serum and dietary vitamin D and cardiovascular disease risk in elderly men: a prospective cohort study. Nutr., Metab. Cardiovasc. Dis. 2012, 22, 856-863.

(7) Motsinger, S.; Lazovich, D.; MacLehose, R. F.; Torkelson, C. J.; Robien, K. Vitamin D intake and mental health-related quality of life in older women: the Iowa Women's Health Study. Maturitas 2012, 71, 267-273.

(8) Pludowski, P.; Holick, M. F.; Pilz, S.; Wagner, C. L.; Hollis, B. W.; Grant, W. B.; Shoenfeld, Y.; Lerchbaum, E.; Llewellyn, D. J.; Kienreich, K.; Soni, M. Vitamin D effects on musculoskeletal health, immunity, autoimmunity, cardiovascular disease, cancer, fertility, pregnancy, dementia and mortality - a review of recent evidence. Autoimmun. Rev. 2013, 12, 976-989.

(9) Holick, M. F. Vitamin D: photobiology, metabolism, and clinical applications. In Endocrinology, 3rd ed.; DeGroot, L. J., Ed.; W. B. Saunders: Philadelphia, PA, USA, 1995; Vol. 2, pp 990-1013.

(10) Tanaka, Y.; Frank, H.; DeLuca, H. F. Biological activity of 1,25dihydroxyvitamin D3 in the rat. Endocrinology 1973, 92, 417-422.

(11) Cashman, K. D.; Seamans, K. M.; Lucey, A. J.; Stocklin, E.; Weber, P.; Kiely, M.; Hill, T. R. Relative effectiveness of oral 25hydroxyvitamin D3 and vitamin D3 in raising wintertime serum 25hydroxyvitamin D in older adults. Am. J. Clin. Nutr. 2012, 95, 13501356.

(12) Jetter, A.; Egli, A.; Dawson-Hughes, B.; Staehelin, H. B.; Stocklin, E.; Gossl, R.; Henschkowski, J.; Bischoff-Ferrari, H. A. Pharmacokinetics of oral vitamin D3 and calcifediol. Bone 2014, 59, 14-19.

(13) Ovesen, L.; Brot, C.; Jakobsen, J. Food contents and biological activity of 25 -hydroxyvitamin $\mathrm{D}$ : a vitamin $\mathrm{D}$ metabolite to be reckoned with? Ann. Nutr. Metab. 2003, 47, 107-113.

(14) Institute of Medicine. Dietary Reference Intakes for Calcium and Vitamin D; National Academies Press: Washington, DC, USA, 2011.

(15) Taylor, C. L.; Carriquiry, A. L.; Bailey, R. L.; Sempos, C. T.; Yetley, E. A. Appropriateness of the probability approach with a nutrient status biomarker to assess population inadequacy: a study using vitamin D. Am. J. Clin. Nutr. 2013, 97, 72-78.

(16) McDonnell, S. L.; French, C. B.; Heaney, R. P. Quantifying the food sources of basal vitamin d input. J. Steroid Biochem. Mol. Biol. 2014, 144 Part A, 149-151.

(17) U.S. Department of Agriculture National Nutrient Database for Standard Reference, http://ndb.nal.usda.gov (accessed July 23, 2015).

(18) Holden, J. M.; Lemar, L. E.; Exler, J. Vitamin D in foods: development of the US Department of Agriculture database. Am. J. Clin. Nutr. 2008, 87, 1092S-1096S.

(19) Saxholt, E.; Christensen, A. T.; Møller, A.; Hartkopp, H. B.; Hess Ygil, K.; Hels, O. H. Danish Food Composition Databank, revision 7, http://www.foodcomp.dk (accessed Aug 19, 2015).

(20) Public Health England McCance and Widdowson's composition of foods integrated dataset' on the nutrient content of the UK food supply, https://www.gov.uk/government/publications/compositionof-foods-integrated-dataset-cofid/ (accessed Aug 19, 2015).

(21) Mattila, P. H.; Valkonen, E.; Valaja, J. Effect of different vitamin $\mathrm{D}$ supplementations in poultry feed on vitamin $\mathrm{D}$ content of eggs and chicken meat. J. Agric. Food Chem. 2011, 59, 8298-8303.

(22) Jakobsen, J.; Clausen, I.; Leth, T.; Ovesen, L. A new method for the determination of vitamin D3 and 25-hydroxyvitamin D3 in meat. J. Food Compos. Anal. 2004, 17, 777-787. 
(23) Huang, M.; LaLuzerne, P.; Winters, D.; Sullivan, D. Measurement of vitamin $\mathrm{D}$ in foods and nutritional supplements by liquid chromatography/tandem mass spectrometry. J. AOAC Int. 2009, 92, 1327-1335.

(24) Burild, A.; Frandsen, H. L.; Poulsen, M.; Jakobsen, J. Quantification of physiological levels of vitamin $\mathrm{D}(3)$ and 25 hydroxyvitamin $\mathrm{D}(3)$ in porcine fat and liver in subgram sample sizes. J. Sep. Sci. 2014, 37, 2659-2663.

(25) Bilodeau, L.; Dufresne, G.; Deeks, J.; Clément, G.; Bertrand, J.; Turcotte, S.; Robichaud, A.; Beraldin, F.; Fouquet, A. Determination of vitamin D3 and 25-hydroxyvitamin D3 in foodstuffs by HPLC UVDAD and LC-MS/MS. J. Food Compos. Anal. 2011, 24, 441-448.

(26) Strobel, N.; Buddhadasa, S.; Adorno, P.; Stockham, K.; Greenfield, H. Vitamin D and 25-hydroxyvitamin D determination in meats by LC-IT-MS. Food Chem. 2013, 138, 1042-1047.

(27) Byrdwell, W. C.; Horst, R. L.; Phillips, K. M.; Holden, J. M.; Patterson, K. Y.; Harnly, J. M.; Exler, J. Vitamin D levels in fish and shellfish determined by liquid chromatography with ultraviolet detection and mass spectrometry. J. Food Compos. Anal. 2013, 30, 109-119.

(28) Phillips, K. M.; Craig Byrdwell, W.; Exler, J.; Harnly, J. M.; Holden, J. M.; Holick, M. F.; Hollis, B. W.; Horst, R. L.; Lemar, L. E.; Patterson, K. Y.; Tarrago-Trani, M. T.; Wolf, W. R. Development and validation of control materials for the measurement of vitamin D3 in selected US foods. J. Food Compos. Anal. 2008, 21, 527-534.

(29) Haytowitz, D. B.; Pehrsson, P. R; Holden, J. M. The National Food and Nutrient Analysis Program: a decade of progress. J. Food Compos. Anal. 2008, 21, S94-S102.

(30) Phillips, K. M.; Patterson, K. Y.; Rasor, A. R.; Exler, J.; Haytowitz, D. M.; Holden, J. M.; Pehrsson, P. R. The role of quality control and reference materials in the National Food and Nutrient Analysis Program. Anal. Bioanal. Chem. 2006, 384, 1341-1355.

(31) Holick, M. F. Vitamin D status: measurement, interpretation, and clinical application. Ann. Epidemiol. 2009, 19, 73-78.

(32) U.S. Pharmacopeia. Oil-soluble vitamins capsules, USP36. In Dietary Supplements Official Monographs; U.S. Pharmacopeia: Rockville, MD, USA, 2012; Vol. 1, pp 1622-1628.

(33) U.S. Pharmacopeia. Oil-soluble vitamins with minerals tablets, USP36. In Dietary Supplements Official Monographs; U.S. Pharmacopeia: Rockville, MD, USA, 2012; Vol. 1, pp 1654-1664.

(34) U.S. Pharmacopeia 38(4) in-process revision: cholecalciferol capsules [NEW] (USP36-NF31 2S), http://www.usppf.com/pf/pub/ index.html (accessed Aug 21, 2015).

(35) International Organization for Standardization, 5725-2:1994. Accuracy (trueness and precision) of measurement methods and results - Part 2: Basic method for the determination of repeatability and reproducibility of a standard measurement method. ISO: Geneva, Switzerland, 1994.

(36) AOAC International. Guidelines and References: Appendix F: Guidelines for Standard Method Performance Requirements, 2012, http://www.eoma.aoac.org/app f.pdf (accessed Feb 4, 2014).

(37) Horwitz, W.; Albert, R. The Horwitz ratio (HorRat): a useful index of method performance with respect to precision. J. AOAC Int. 2006, 89, 1095-1109.

(38) Massart, D. L.; Smeyers-Verbeke, J.; Vander Heyden, Y. Benchmarking for analytical methods: the Horwitz curve. LCGC Eur. 2005, 18, 528-531.

(39) LeDoux, M. A.; Appelhans, K. R.; Braun, L. A.; Dziedziczak, D.; Jennings, S.; Liu, L.; Osiecki, H.; Wyszumiala, E.; Griffiths, J. A quality dietary supplement: before you start and after it's marketed - a conference report. Eur. J. Nutr. 2015, 54 (Suppl. 1), S1-S8.

(40) Kuhn, J.; Schutkowski, A.; Kluge, H.; Hirche, F.; Stangl, G. I. Free-range farming: a natural alternative to produce vitamin Denriched eggs. Nutrition 2014, 30, 481-484.

(41) Casas, E.; Lippolis, J. D.; Kuehn, L. A.; Reinhardt, T. A. Seasonal variation in vitamin $\mathrm{D}$ status of beef cattle reared in the central United States. Domest. Anim. Endocrinol. 2015, 52, 71-74.

(42) Sunita Rao, D.; Raghuramulu, N. Food chain as origin of vitamin D in fish. Comp. Biochem. Physiol. A Physiol. 1996, 114, 15-19.
(43) Cherian, G. Eggs and health: nutrient sources and supplement carriers. Eggs and health: nutrient sources and supplement carriers. In Complementary and Alternative Therapies and the Aging Population; Watson, R. R., Ed.; Academic Press: New York, 2009; pp 333-346.

(44) Lu, Z.; Chen, T. C.; Zhang, A.; Persons, K. S.; Kohn, N.; Berkowitz, R.; Martinello, S.; Holick, M. F. An evaluation of the vitamin D3 content in fish: is the vitamin D content adequate to satisfy the dietary requirement for vitamin D? J. Steroid Biochem. Mol. Biol. 2007, 103, 642-644.

(45) Kassis, N.; Drake, S. R.; Beamer, S. K.; Matak, K. E.; Jaczynski, J. Development of nutraceutical egg products with omega-3-rich oils. LWT Food Sci. Technol. 2010, 43, 777-783.

(46) Schiavone, A.; Barroeta, A. C. Egg enrichment with vitamins and trace minerals. In Improving the Safety and Quality of Eggs and Egg Products: Egg Safety and Nutritional Quality; Van Immerseel, F., Nys, Y., Bain, M., Eds.; Woodhead Publishing Limited: Cambridge, UK, 2011; pp 289-320.

(47) Jakobsen, J.; Saxholt, E. Vitamin D metabolites in bovine milk and butter. J. Food Compos. Anal. 2009, 22, 472-478.

(48) Jakobsen, J.; Maribo, H.; Bysted, A.; Sommer, H. M.; Hels, O. 25-Hydroxyvitamin D3 affects vitamin D status similar to vitamin D3 in pigs - but the meat produced has a lower content of vitamin D. Br. J. Nutr. 2007, 98, 908-913.

(49) Exler, J.; Phillips, K. M.; Patterson, K. Y.; Holden, J. M. Cholesterol and vitamin D content of eggs in the U.S. retail market. J. Food Compos. Anal. 2013, 29, 110-116.

(50) Clausen, I.; Jakobsen, J.; Leth, T.; Ovesen, L. Vitamin D3 and 25-hydroxyvitamin D3 in raw and cooked pork cuts. J. Food Compos. Anal. 2003, 16, 575-585.

(51) Schmid, A.; Walther, B. Natural vitamin D content in animal products. Adv. Nutr. 2013, 4, 453-462.

(52) National Institute of Standards and Technology Standard Reference Materials, http://www.nist.gov/srm (accessed May 22, 2015). 